Iwona Polucha, $\mathrm{PhD}$

University of Warmia and Mazury in Olsztyn, Poland Faculty of environmental management and agriculture Department of landscape architecture E-mail: iwona.polucha@uwm.edu.pl ORCID ID 0000-0002-8283-1785

\title{
SENSORY-EDUCATIONAL SPACE - PROPOSALS OF DEVELOPMENT OF THE SCHOOL AREA FOR NEEDS OF YOUTH
}

\begin{abstract}
This article focused on issues of development of school areas from the perspective of modern education. The space at the schools can fulfill a number of functions: sport, cultural, educational and sensory. The use of educational elements of area equipment associated with the composed greenery stimulating senses, allows to conduct lessons in open space and attractive spending of breaks. There are needed in the school areas not only sport objects, also sensory equipment for performing of experiments and encourage to learning in the garden. In the school space should be compose plant species that favor the development of sensory of learners.
\end{abstract}

Keywords: sensory space, education, educational institution, green area

\section{PRZESTRZEN SENSORYCZNO-EDUKACYJNA - PROPOZYCJE ZAGOSPODAROWANIA TERENU SZKOLNEGO NA POTRZEBY MLODZIEŻY}

Streszczenie. Niniejszy artykut porusza problematykę zagospodarowania terenów szkolnych z perspektywy założeń nowoczesnej edukacji. Przestrzeń przy szkołach może petnić szereg funkcji: reprezentacyjna, sportowa, kulturalna, dydaktyczna oraz szeroko rozumiana funkcje sensoryczna. Zastosowanie edukacyjnych elementów wyposażenia, powiązanych z zielenia komponowana stymulująca zmysty, pozwala na prowadzenie zajęć lekcyjnych i pozalekcyjnych na świeżym powietrzu oraz atrakcyjne spędzanie przerw międzylekcyjnych. Warto wprowadzać do tej przestrzeni nie tylko obiekty sportowe, ale także instalacje sensoryczne umożliwiajace wykonywanie doświadczeń $i$ zachęcajace do nauki w ogrodzie. W przestrzeni przyszkolnej powinny być skomponowane nasadzenia takich gatunków roślin, które sprzyjają rozwojowi sensorycznemu uczniów.

Slowa kluczowe: przestrzeń sensoryczna, edukacja, placówka dydaktyczna, teren zieleni

\section{Wprowadzenie i cel badań}

Nowoczesna edukacja, dążąca do rozwoju kreatywności uczniów, przenosi się do otwartej przestrzeni. W otoczeniu przyrodniczym istnieje dużo więcej możliwości

Development of the school area
Materials of International Practical Internet Conference "Challenges of Science" 
zaprezentowania praktycznych aspektów wykorzystania wiedzy oraz odwołania się do doświadczeń uczniów. Uczniowie chętnie uczestniczą w niestandardowych zajęciach. Wyjście na zewnątrz szkoły budzi ciekawość, zachęca do wspólnych rozważań nad przebiegiem prezentowanych zagadnień. Zakres każdego przedmiotu szkolnego pozwala wybrać treści, które można omówić w otoczeniu szkoły. Niektóre przedmioty można realizować bez większych zmian na terenie szkolnym, inne wymagają wprowadzenia dodatkowych rozwiązań w postaci instalacji ogrodowych lub elementów małej architektury. Dzięki wcześniejszej aranżacji przestrzeni przyszkolnej, każdy nauczyciel jest w stanie zainicjować realizację wybranych zajęć na świeżym powietrzu. W przestrzeni ogrodowej można wykonywać doświadczenia $\mathrm{z}$ zakresu fizyki czy astronomii, eksperymenty z chemii, inscenizować znane utwory, poznawać słówka $z$ języka obcego, fakty historyczne, pogłębiać wiedzę z geografii, rozwijać umiejętności plastyczne i muzyczne itp. Otoczenie przyrody ułatwia przekaz wiedzy biologicznej, w otwartej przestrzeni można w obrazowy i przystępny sposób przekazać więcej informacji niż podczas standardowej lekcji w budynku szkolnym.

Podjęte badania wpisują się w potrzebę podejmowania inicjatyw, które stworzą uczniom warunki do nauki w otwartej przestrzeni i sprzyjają integracji sensorycznej, także w czasie przerw międzylekcyjnych i po lekcjach. Wielogodzinny pobyt w szkołach, w murach budynku, można urozmaicić przenosząc do ogrodu szkolnego realizację wybranych tematów zajęć z różnych przedmiotów. Innowacyjna kreacja przestrzeni przy szkołach jest działaniem zmierzającym w kierunku nowoczesnej edukacji. Praca w środowisku zewnętrznym pozwala bowiem w niestandardowy sposób zaspokajać emocjonalne i fizyczne potrzeby uczniów.

\section{Istota przestrzeni sensoryczno-edukacyjnej}

Określenie „sensoryczny” oznacza doznawany za pomocą zmysłów [Słownik... 1995]. Każdy ogród może mieć cechy założenia sensorycznego, w otoczeniu zieleni są stymulowane różne zmysły. Szczególnie intensywna jest percepcja wzrokowa, ale szereg bodźców jest odbieranych także za pomocą innych zmysłów takich, jak: słuch, węch, dotyk, smak, chociaż zawsze towarzyszą im spostrzeżenia wzrokowe [Pawłowska 2008].

Ogrody zmysłów to założenia mające na celu ukazanie wielowymiarowości i wzajemnych powiązań między poszczególnymi zmysłami. Dobór gatunków roślin, nawierzchni i małej architektury jest ukierunkowany na dostarczanie bodźców i wywoływanie różnorodnych wrażeń zmysłowych. Dzięki aranżacji uwzględniającej instalacje sensoryczne i pomoce dydaktyczne ta grupa założeń, doskonale pełni funkcje edukacyjne i terapeutyczne.

W ogólnym zarysie przestrzeń sensoryczno-edukacyjną można zdefiniować jako teren z zielenią komponowaną i elementami wyposażenia, które stymulują ludzkie zmysły i inspirują do nauki, wpływając na rozwój fizyczny i psychiczny użytkowników. Celem kreowania takiej przestrzeni przy szkołach jest stworzenie warunków do niestandardowego nauczania w inspirującym środowisku zachęcającym uczniów do postępu edukacyjnego.

\section{Znaczenie terapeutyczne ogrodów sensorycznych}

Dobroczynny wpływ ogrodów doceniano już w starożytności, jednak wykorzystywanie ich w celach terapeutycznych nastąpiło na przełomie XVII i XIX wieku, początkowo w Stanach Zjednoczonych, Anglii i Hiszpanii. W 1936 roku w Anglii, ogrodnictwo uznano za oficjalną metodę terapii dla fizycznie i psychicznie chorych, a dziewiętnaście lat później w USA przyznano pierwszy tytuł magistra $\mathrm{w}$ tej dziedzinie. Zrozumienie związku między ludźmi $\mathrm{i}$ zielenią pozwoliło na szerokie wykorzystanie tej wiedzy $\mathrm{w}$ terapii kierowanej do osób $\mathrm{z}$ wszelkiego rodzaju zaburzeniami, umysłowymi, psychicznymi, fizycznymi, sensorycznymi, geriatrycznymi. Terapia ogrodnicza opiera się na zasadach podkreślających korzyści, jakie

Development of the school area
Materials of International Practical Internet Conference "Challenges of Science" 
człowiek czerpie z kontaktu z roślinami. Teoria „przeciążenia i pobudzenia” głosi, że współczesny człowiek atakowany hałasem, ruchem i ciągle zmieniającymi się obrazami przytłaczającymi zmysły i wyniszczającymi organizm, może znaleźć ukojenie i relaks w środowisku naturalnym, wypełnionym przez rośliny, gdzie wszystko jest zrozumiałe i nieskomplikowane. Teoria biofilii natomiast, podkreśla istnienie wrodzonych, pozytywnych reakcji człowieka na środowisko naturalne i żywe organizmy, zapewniające poczucie bezpieczeństwa i spokoju. Terapia ogrodnicza, jedna $\mathrm{z}$ form terapii uzupełniających tradycyjne metody terapii i rehabilitacji, rozumiana jest jako wykonywanie wszelkiego rodzaju prac ogrodniczych, przynoszących satysfakcję, poprawę zdrowia fizycznego, psychicznego i ogólnego samopoczucia. Korzystnie wpływa także terapia bierna polegająca na przebywaniu w ogrodzie, bądź sam widok roślin. Rośliny, prace ogrodnicze i wrodzony związek człowieka z naturą stanowią podstawowe narzędzia w procesie hortiterapii. Ogrody, w których prowadzone są zajęcia terapeutyczne, należy projektować z uwzględnieniem potrzeb korzystających z nich osób. Dobrze dobrana terapia w odpowiednio dostosowanym miejscu przynosi znakomite efekty. Spośród wielu, warto nadmienić wzrost poczucia własnej wartości, poprawę koncentracji, naukę samodzielności, obniżenie stresu i napięć, zwiększenie koordynacji ruchowej i równowagi. Profesjonalnie prowadzona terapia ogrodnicza koncentruje się na pracach z żywym materiałem roślinnym, ogrodowych bądź szklarniowych, jak przygotowanie gleby, siew, sadzenie roślin, podlewanie. Duże zainteresowanie wzbudza pielęgnacja roślin, a także zajęcia z florystyki [Latkowska 2008]. Hortiterapia może być z powodzeniem włączana do programów nauczania, przynosząc wiele korzyści dzieciom i młodzieży w wieku szkolnym.

\section{Inspiracje w aranżacji przestrzeni sensoryczno-edukacyjnej}

Oddziaływanie sensoryczne można wykorzystać do rozwoju funkcji edukacyjnej i rekreacyjnej terenów zieleni przy placówkach dydaktycznych. Edukacja oznaczająca wychowanie czy zdobywanie wykształcenia może być realizowana w otwartej przestrzeni poprzez stymulowanie różnych zmysłów. W Krakowie w Parku Lotników Polskich w dzielnicy Czyżyn powstał pierwszy w Polsce park edukacyjny - Ogród Doświadczeń im. Stanisława Lema. Realizacja była inspirowana istniejącym już od 1996 roku „Polem Doświadczeń Zmysłowych", jak nazwano park miejski znajdujący się w centrum Norymbergii. Autorem Norymberskiego parku był wszechstronnie wykształcony Hugo Kukelhaus - matematyk, filozof i psycholog, a przede wszystkim pasjonat zabawek edukacyjnych [Ogród doświadczeń... 2007]. Krakowski projekt nawiązuje do idei ogrodu sensorycznego, ponieważ znajdujące się w nim instalacje badawcze, swym działaniem oddziaływają na ludzkie zmysły [Gołąb 2007]. Cały park rozciąga się na 6-hektarowym obszarze. W Ogrodzie Doświadczeń znajduje się ponad 50 instalacji w otoczeniu drzew i krzewów. Każda z instalacji reprezentuje określone zjawisko przyrody, które można uzyskać poprzez „osobiste doświadczenie $i$ przeżywanie zjawisk fizycznych, z udziatem własnych zmystów, próbować rozumieć świat otaczajacych nas zjawisk" [Ogród doświadczeń... 2007]. Kluczowym celem koncepcji Ogrodu Doświadczeń było zachęcenie odwiedzających do uczestnictwa w poznawaniu przyrody, poprzez czynniki sensoryczne i interaktywne. W edukacji istotne jest, aby proces poznawania był inspirujący, ciekawy, a także był dobrą zabawą [Gołąb 2007].

Atrakcyjny ogród doświadczeń znajduje się w Deanfoss Universe w Nordborg, na wyspie Als w południowej części Danii, którego pomysłodawcą był Mads Clausen. Odwiedzający ogród mogą poznać prawa rządzące naturą oraz świat nauki, który towarzyszy nam również w życiu codziennym. Niewątpliwie interesującym zjawiskiem w ogrodzie jest niebieska kostka zwana Blue Cube, jej konstrukcja została tak rozplanowana, aby po zewnętrznych ścianach

Development of the school area
Materials of International Practical Internet Conference "Challenges of Science" 
spływała woda. Widowisko tworzy „ciekłą elewację”, dzięki czemu odbija promienie słoneczne [Drozdek 2010].

Arboretum i zakład Fizjografii w Bolestraszycach w Polsce utworzony w 1973 roku, jest kolejnym przykładem o tematyce sensorycznej. Sensualny Ogród Uniwersalny - taką nazwę nosi założenie, jest przystosowany do poznawania otoczenia wszystkimi zmysłami. Ciągi w ogrodzie są zaplanowane $\mathrm{w}$ taki sposób, aby zwiedzający sam mógł odkrywać trasę zwiedzania. Nawierzchnie dróg, wykonane $\mathrm{z}$ materiałów wysokiej technologii, pozwalają na odbiór informacji przy pomocy zmysłu wzroku i dotyku. Zaprojektowana roślinność uwzględnia m.in. potrzeby osób niewidomych, jak i poruszającym się na wózku [Piórecki 2010]. Ogród sensoryczny przeważnie oferuje odbiór wrażeń za pomocą wszystkich zmysłów. Popularne są tzw. ogrody zapachowe, dzięki starannie dobranym gatunkom kwiatów, można uzyskać wyjątkowe efekty [Pawłowska 2008]. Na terenie ogrodu sensualnego funkcjonuje ,galeria przez dotyk", czyli wystawa przedstawiająca wiklinowe i ceramiczne rzeźby, stworzone przez studentów Wydziału Artystycznego Uniwersytetu Marii Cure-Skłodowskiej w Lublinie [Piórecki 2010].

Dźwięk jest ważnym elementem ogrodu sensorycznego, stanowi bowiem rodzaj „tworzywa” w kompozycji ogrodu [Pawłowska 2008]. Efekty dźwiękowe w powiązaniu z innymi elementami przyrody, uzupełniają krajobraz, wnosząc do niego nową treść i tworząc specyficzną atmosferę [Bernat 2008]. Przykładem założenia, w którym wykorzystano efekty dźwiękowe, jest jeden z tzw. kieszonkowych parków (pocket parks) - GreenAcre Park. Te małe pod względem rozmiarów, lecz wybitne dzieło znajduje się w Nowym Jorku na Manhattanie. Najważniejszym elementem tego założenia jest ściana symulująca wodospad o wysokości 7,6 $\mathrm{m}$, dająca egzotyczny nastrój miejscu. Inne ściany porośnięte są bujnymi pnączami, co tworzy biologicznie czynny zasób zieleni, a wzdłuż nich płynie woda. Przebywając w parku w otoczeniu bujnej zieleni, można usłyszeć jedynie dźwięki dochodzące z wodospadu, co pozwala zapomnieć o przepełnionych hałasem ulicach. Koncepcja GreenAcre Park, za pomocą naturalnych materiałów wykorzystuje efekty, które odbiera się za pomocą zmysłu wzroku, słuchu, dotyku, a także zapachu [Pawłowska 2008].

Przyrodniczy Ogród Zmysłów znajdujący się przy dyrekcji Parku Narodowego Ujście Warty w Polsce stanowi przykład założenia spełniającego głównie funkcję edukacyjną. Całość podzielona jest na siedem głównych punktów dydaktycznych, nastawionych na interaktywne poznawanie przyrody. Najważniejszym z nich jest "ogródek zmysłów" prezentujący bogactwo zapachów i faktur świata roślin. W „ogrodzie motyli” rośliny dobierano pod kątem zdolności wabienia tych owadów. Ciekawym pomysłem jest podzielona na odcinki o zróżnicowanej nawierzchni „ścieżka zmysłów”, po której z założenia chodzi się boso. Orientację w terenie ułatwiają rozmieszczone przy każdym z punktów Przyrodniczego Ogrodu Zmysłów tablice, na których znajdują się najważniejsze informacje na temat atrakcji i roślin występujących w danym punkcie [Wypychowska 2002].

Projekt Ogrodu Zmysłów na Bielanach w Warszawie jest kolejnym przykładem niezwykłego parku umożliwiającego odbiór przyrody nie tylko za pomocą wzroku, lecz poprzez wykorzystanie wszystkich zmysłów. Poza doborem charakterystycznych roślin, projekt wprowadza elementy małej architektury. Wybrane fragmenty parku będą stanowić swoiste terapeutyczne „mini-ogrody”. W części oddziałującej na zmysł dotyku, zaplanowano urządzenia do zabaw, które ze względu na oryginalny kształt i fakturę, będą pobudzać wyobraźnię dzieci i uczyć rozpoznawania różnorodnych kształtów. Pluskające i szumiące zabawki wodne, ogrodowe instrumenty muzyczne wprowadzone $\mathrm{w}$ części stymulującej słuch, poza działaniem relaksacyjnym, wykazują właściwości terapeutyczne [Gruza 2009].

Development of the school area
Materials of International Practical Internet Conference "Challenges of Science" 
Ważnym przykładem, uznawanym za jeden z najbardziej innowacyjnych, mogą być otwarte w 2007 roku, ogrody sensoryczne Ogrodu Botanicznego Wybrzeża Maine w Boothbay w Stanach Zjednoczonych. Na powierzchni wielkości około 1 ha, znany architekt Herb Schaal zaprojektował ogrody oddziałujące na każdy z pięciu zmysłów. Wszyscy użytkownicy, w szczególności ci z dysfunkcjami jednego lub kilku zmysłów, mogą odbierać przyrodę za pomocą specjalnego, atrakcyjnego przekazu. Pięć odrębnych części: zapachu, smaku, wzroku, dotyku i dźwięki zaprojektowano w sposób zgodny z jej przeznaczeniem. Do najciekawszych pomysłów zastosowanych w projekcie nalezą: barwne, kontrastowe rabaty oddziałujące na wzrok, kamienne fontanny zachęcające do skosztowania wody, ocienione pergole i głazy narzutowe stanowiące miejsce wypoczynku, szumiące stawy z fontannami i kaskadami. Dodatkową atrakcją jest klasyczny labirynt, którego wzór wykonano z dużych, gładkich kamieni [http://www.mainegardens.org/discover/image-galleries/seasons-summer].

\section{Obiekt i metody badań}

Badania wykonano w przestrzeni przyszkolnej przy V Liceum Ogólnokształcącym im. Wspólnej Europy w Olsztynie, stolicy Warmii i Mazur w Polsce. Szkoła została powołana w 1989 r. i od 2010 r. należy do Zespołu Szkół Nr 7. Siedzibą placówki jest nowoczesny budynek z terenem, na którym znajdują się boiska piłki siatkowej i ręcznej oraz korty tenisowe. Ogólna liczba uczniów w liceum wynosi 608. Powierzchnia terenu zieleni wokół szkoły wynosi 4,2 ha (dane z listopada 2013 r.).

Badania służące stworzeniu kreatywnego ogrodu dla młodzieży obejmowały prace terenowe polegające na wykonaniu inwentaryzacji zieleni, nawierzchni, małej architektury. Ich uzupełnieniem były analizy zgromadzonych dokumentów, materiałów kartograficznych oraz literatury. Ważne informacje uzyskano w trakcie badań sondażowych z uczniami oraz podczas wywiadu z pracownikami placówki. Zasadniczą część badań stanowiły prace projektowe związane $\mathrm{z}$ określeniem funkcji poszczególnych fragmentów terenu, ustaleniem wytycznych do projektowania oraz sporządzeniem przykładowych koncepcji projektowych zagospodarowania przestrzeni przy wybranej szkole. Zaproponowane rozwiązania są rezultatem zainicjowanego przez autorkę projektu zachęcającego placówki edukacyjne w stolicy Warmii i Mazur w Polsce do współpracy z młodymi projektantami terenów zieleni i architektami krajobrazu, pod hasłem „Ogród z klasą - przestrzeń z wyobraźnią".

\section{Wyniki sondażu wśród uczniów badanej placówki dydaktycznej}

Sondaż diagnostyczny miał na celu zapoznanie się z oczekiwaniami użytkowników terenu przy Liceum Ogólnokształcącym nr 5 w Olsztynie odnośnie przyszłych funkcji i wyglądu tej przestrzeni. W badaniach przeprowadzonych w roku szkolnym 2010/11 uczestniczyło 100 uczniów. Pośród uczestników badań, 28 osób - reprezentowało klasy pierwsze, 29 - klasy drugie, a 43 - klasy trzecie. We wszystkich pytaniach respondenci mieli możliwość wyboru kilku odpowiedzi.

Wykonane badania ukazują otwartość uczniów na wprowadzenie zmian w programie nauczania poprzez realizację wybranych zajęć w otwartej przestrzeni. Zasugerowali szereg propozycji zagospodarowania terenu szkolnego, które umożliwiłyby pogłębianie wiedzy $\mathrm{z}$ różnych przedmiotów. W innowacyjnie zaaranżowanym otoczeniu szkoły chętnie spędzaliby także przerwy międzylekcyjne i uczestniczyliby w zajęciach pozalekcyjnych. Uczniowie zadeklarowali także aktywny udział $w$ zabiegach pielęgnacyjnych i pracach związanych $\mathrm{z}$ utrzymywaniem porządku na terenie szkolnym. Ich potrzeby, oczekiwania i pomysły dotyczące przestrzeni ogrodowej przy szkole przedstawiono na rysunkach 1-9.

Development of the school area
Materials of International Practical Internet Conference "Challenges of Science" 


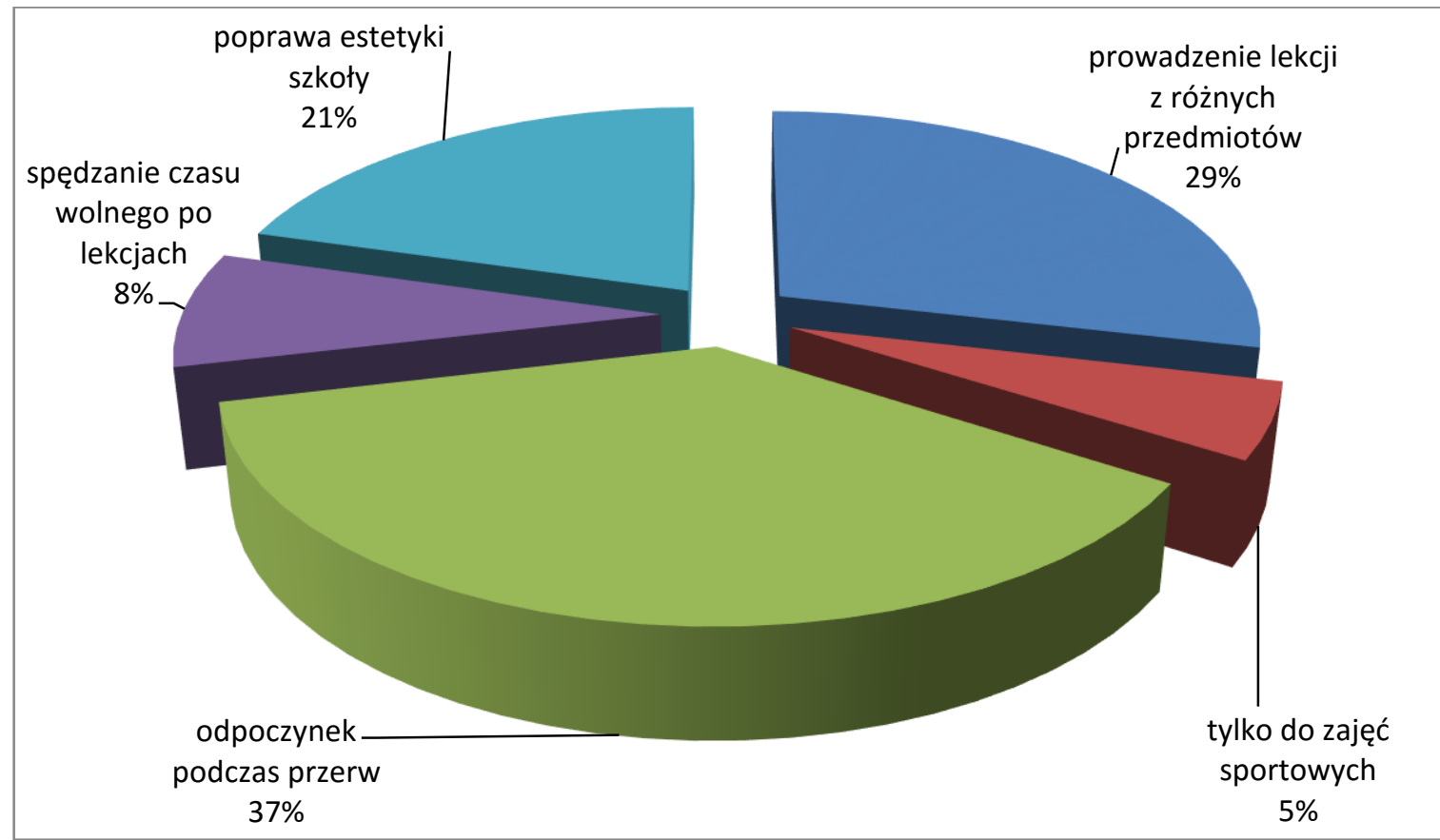

Rys. 1. Opinie uczniów na temat możliwości wykorzystania terenu zieleni przy LO Vw Olsztynie

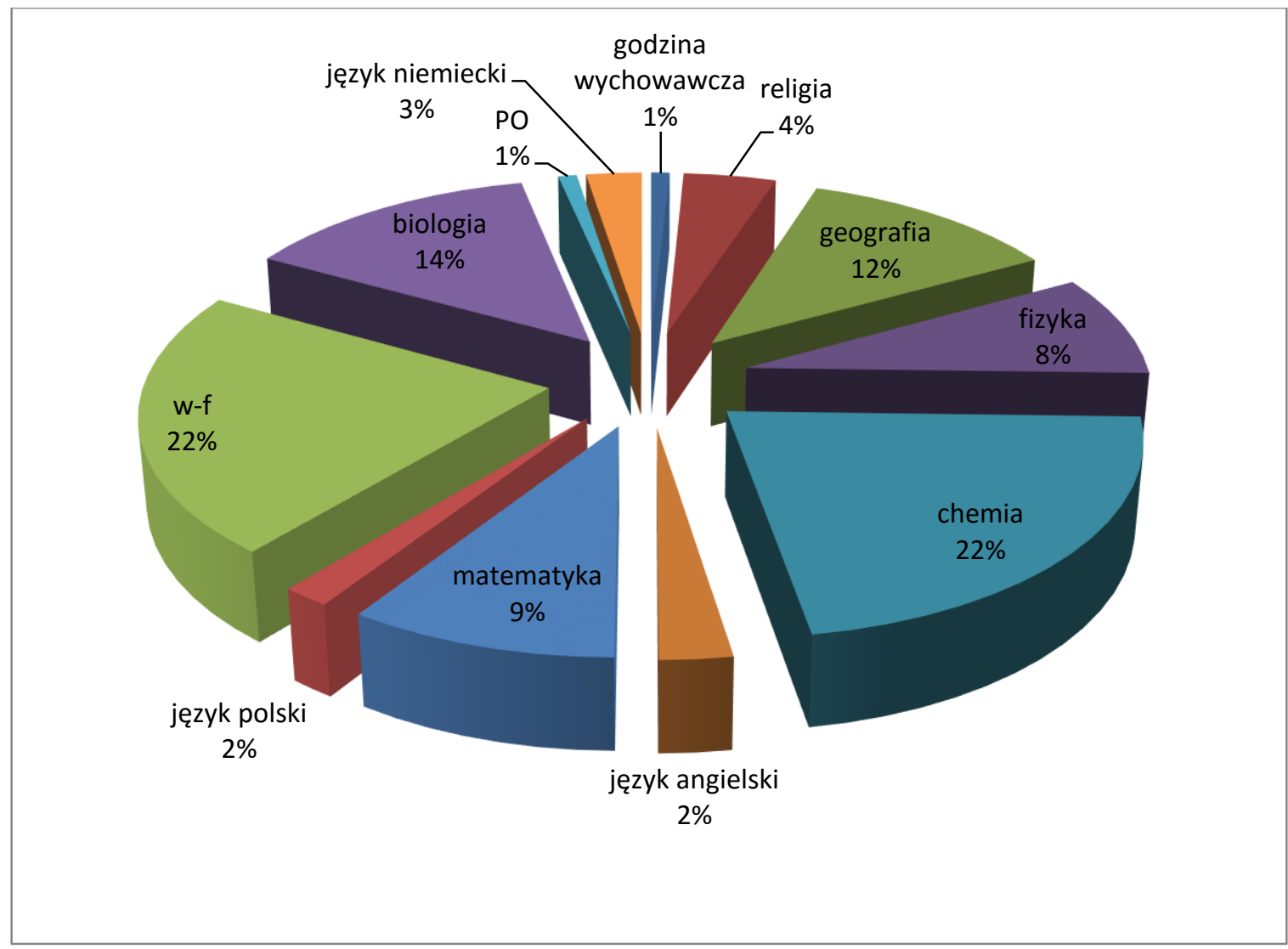

Rys. 2. Ulubione przedmioty uczniów LO Vw Olsztynie

Development of the school area
Materials of International Practical Internet Conference "Challenges of Science" 


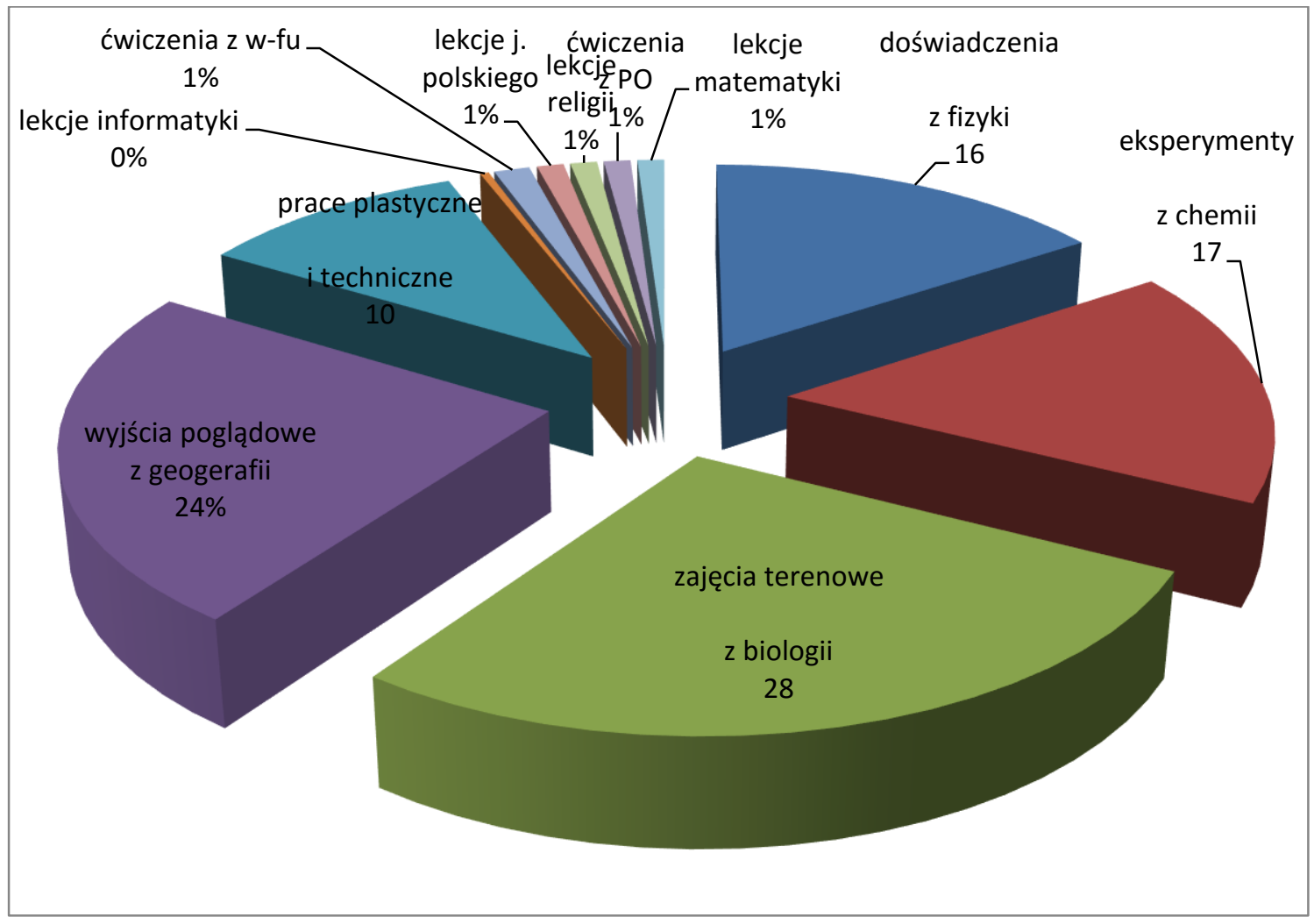

Rys. 3. Wskazania uczniów odnośnie zajęć, które chcieliby realizować w przestrzeni przyszkolnej

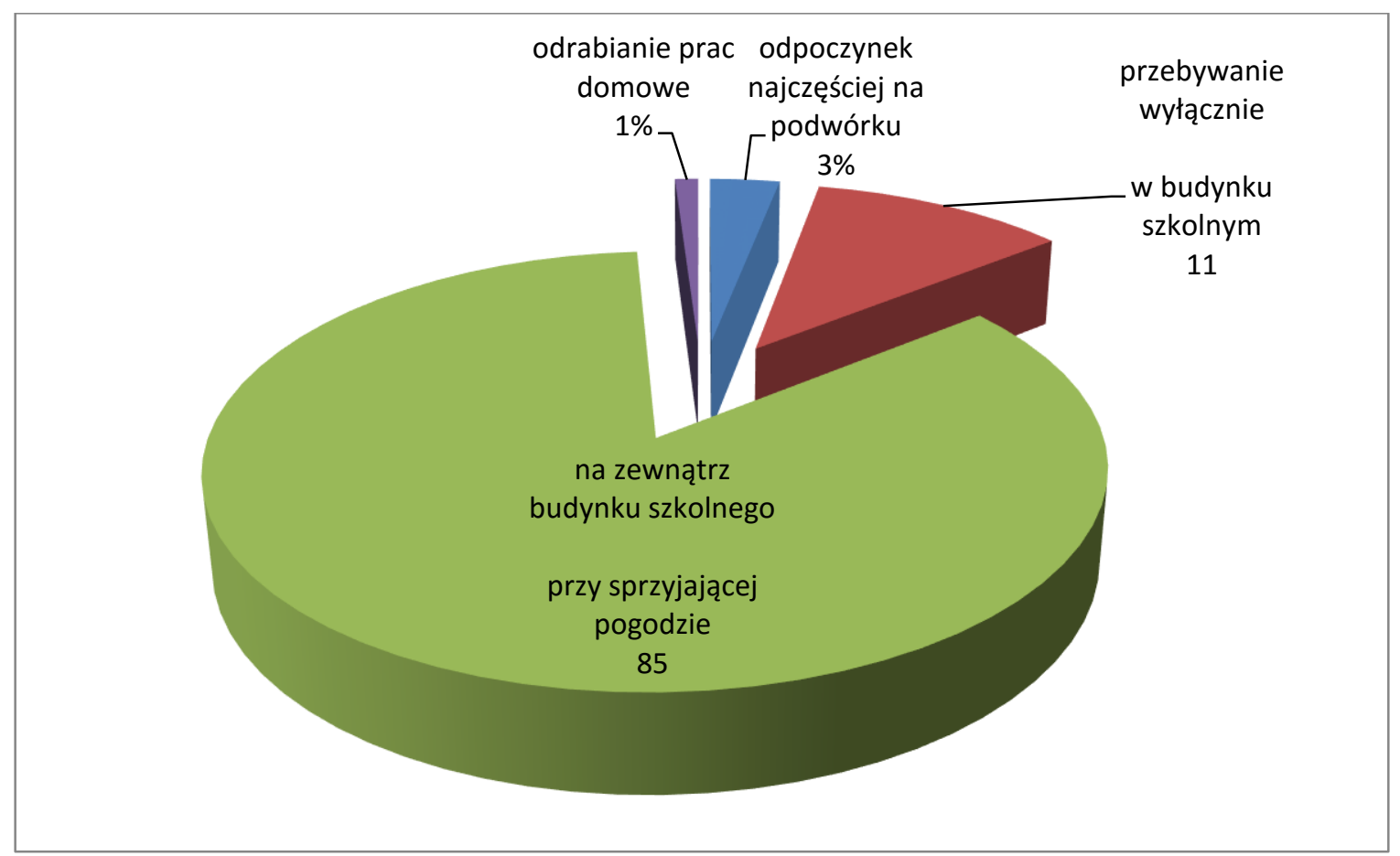

Rys. 4. Aktualnie wybierane przez uczniów sposoby spędzania przerw międzylekcyjnych

Development of the school area
Materials of International Practical Internet Conference "Challenges of Science" 


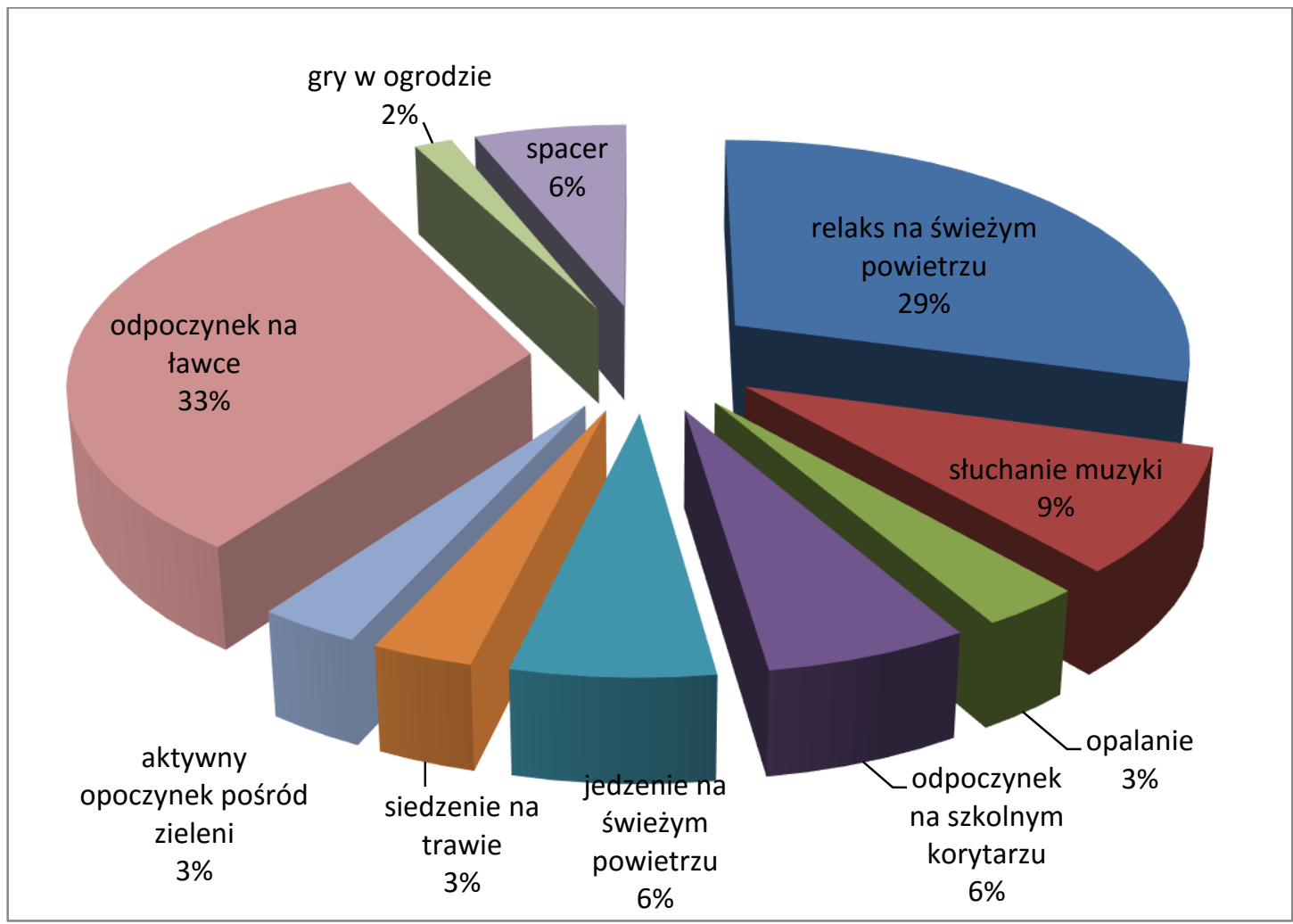

Rys. 5. Preferowane przez uczniów sposoby spędzania przerw międzylekcyjnych

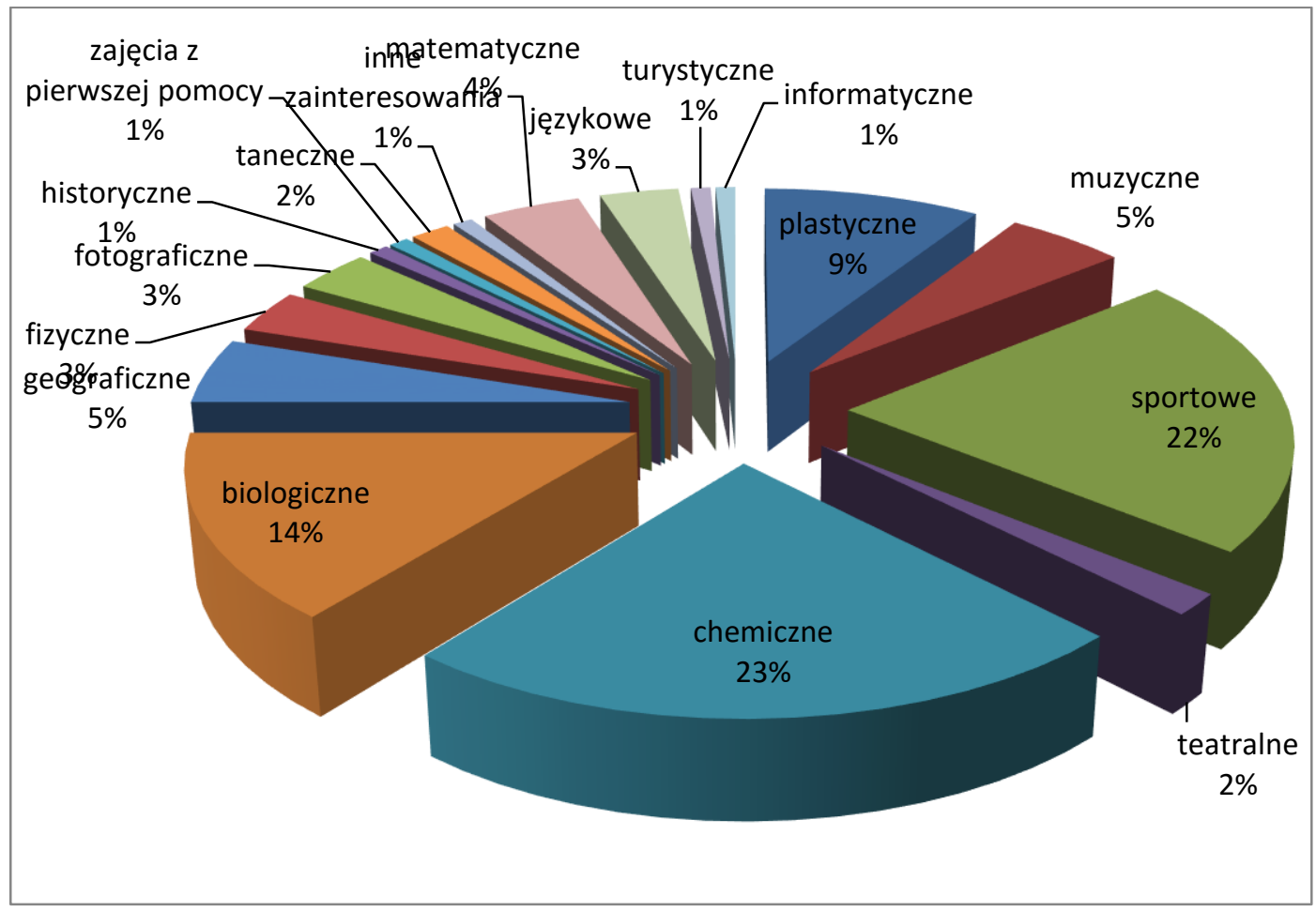

Rys. 6. Zainteresowania rozwijane przez uczniów po zajęciach lekcyjnych

Development of the school area
Materials of International Practical Internet Conference "Challenges of Science" 


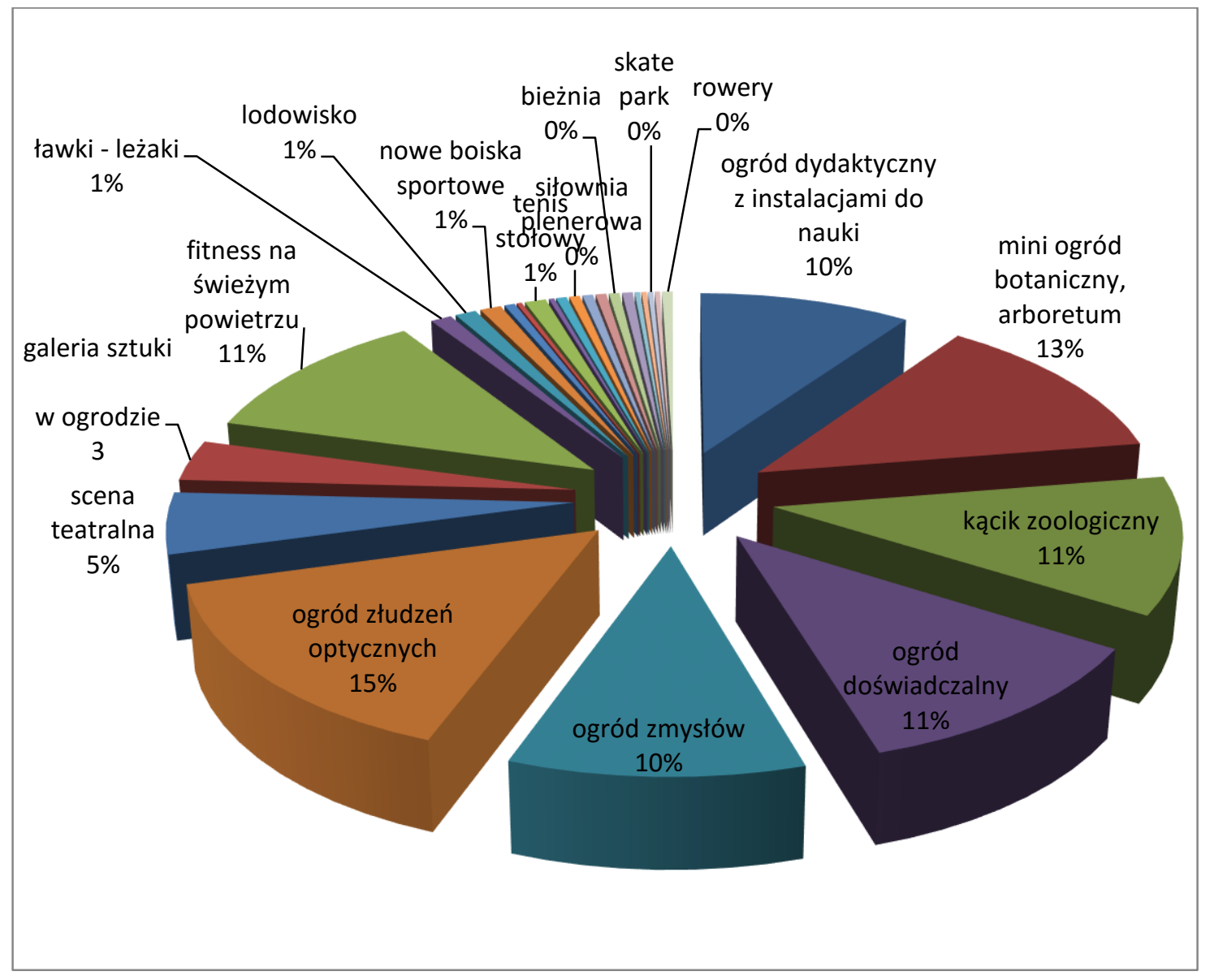

Rys. 7. Wybrane przez uczniów propozycje zagospodarowania terenu zieleni przy LO V w Olsztynie

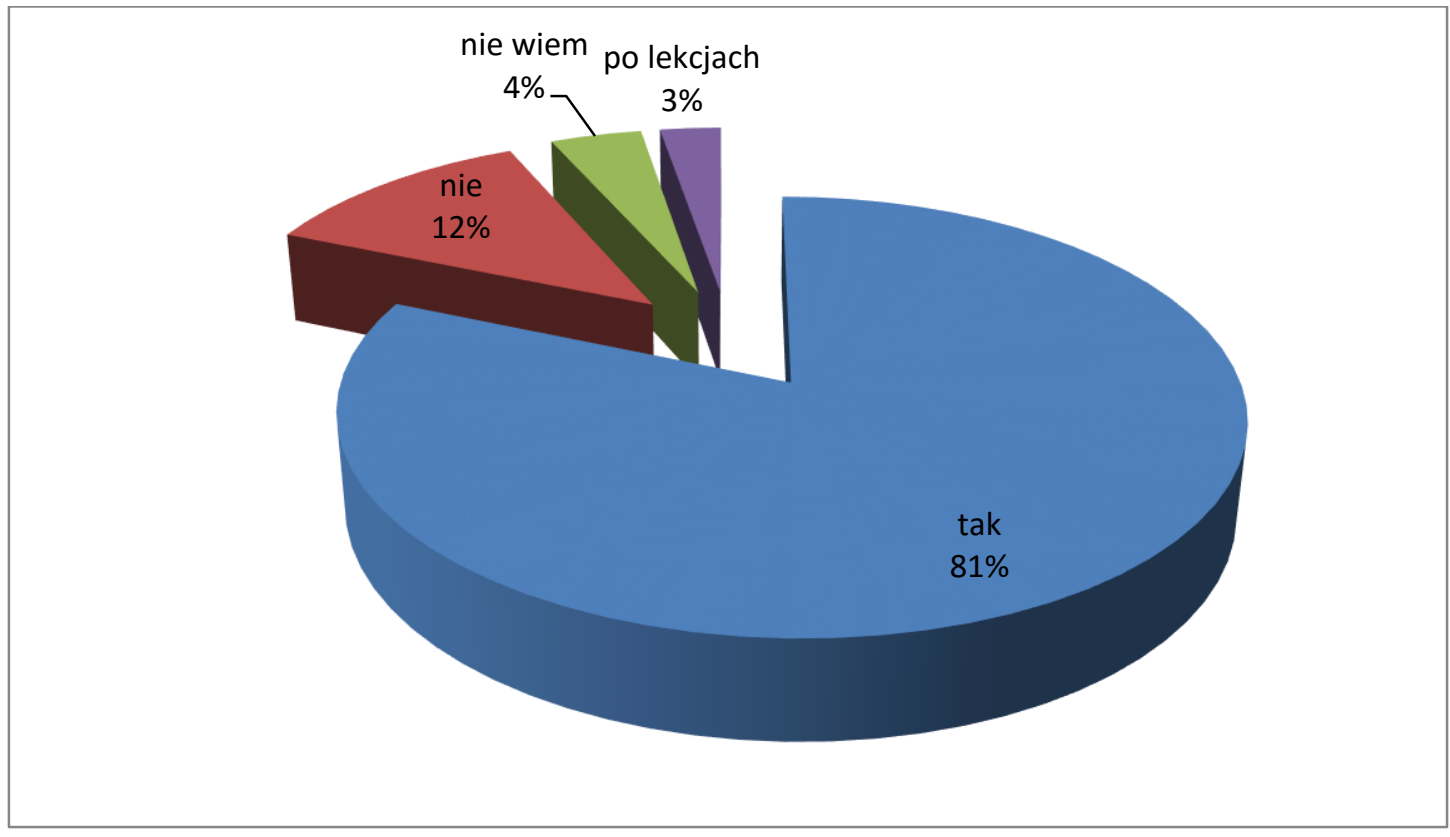

Rys. 8. Deklaracje uczniów dotyczace udziału w pracach ogrodowych na terenie szkoty

Development of the school area
Materials of International Practical Internet Conference "Challenges of Science" 


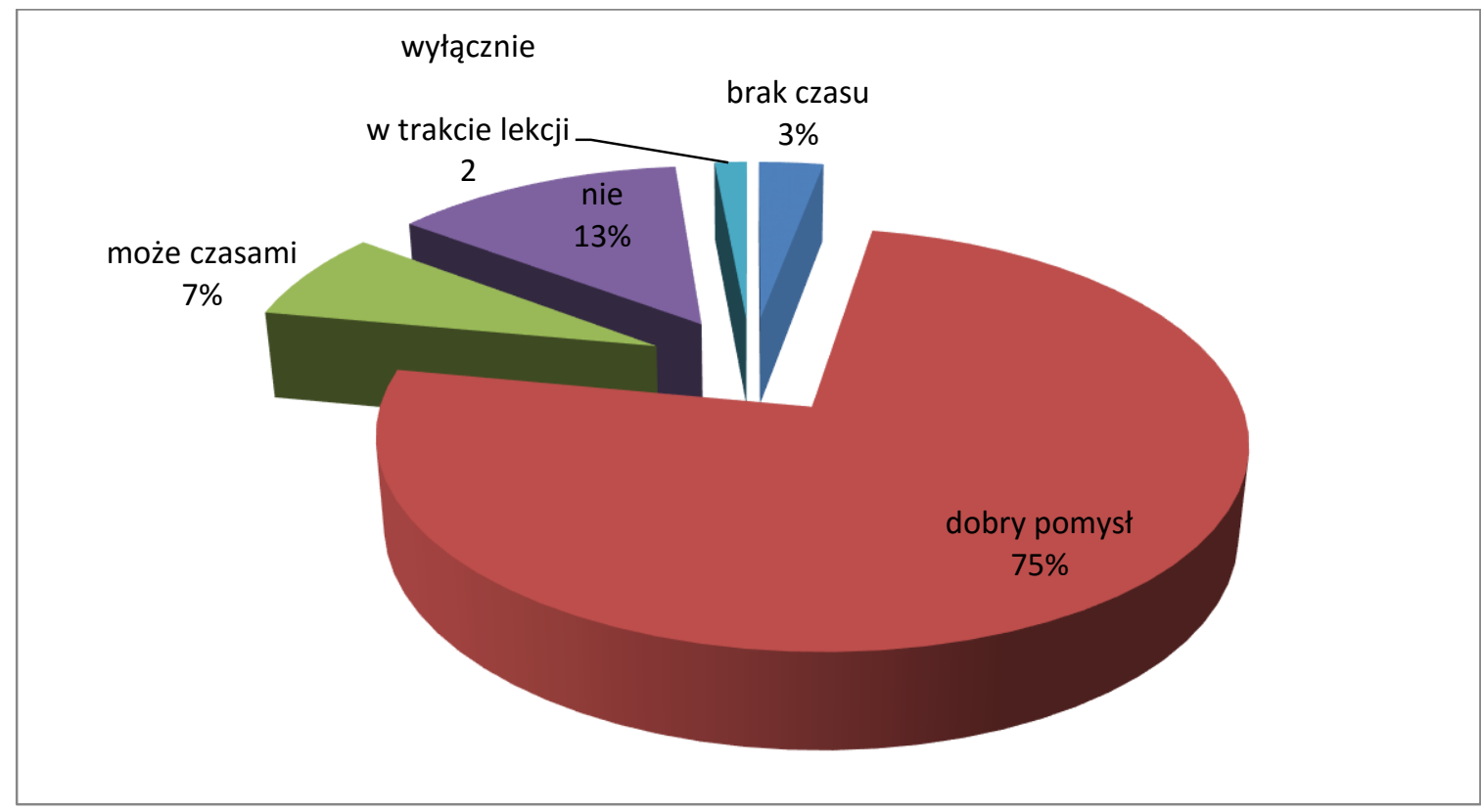

Rys. 9. Akceptacja przez uczniów pomysłu organizowania spotkań po lekcjach w obrębie szkolnego terenu zieleni (np. artystycznych spotkań plenerowych, integracyjnych, imprez muzycznych)

Źródto rys. 1-9: opracowanie własne

\section{Wyniki wywiadu z pracownikami badanej placówki dydaktycznej}

Przedstawiciele Dyrekcji szkoły dostrzegali potrzebę zagospodarowania terenu wokół placówki na cele edukacyjne z uwzględnieniem funkcji sensorycznej. Sugerowali, że warto wyznaczyć miejsce na tzw. „zieloną klasę”, z ławkami wśród zieleni, gdzie odbywałyby się lekcje na świeżym powietrzu. W opinii Dyrekcji, zagospodarowany teren zieleni pełniłby funkcję demonstracyjną dla dzieci i młodzieży z okolicznych gimnazjów i szkół podstawowych oraz uczniów badanego liceum. Pośród zasugerowanych podczas wywiadu propozycji zagospodarowania przestrzeni przy szkole (jak m.in.: mini ogród dydaktyczny, botaniczny, zoologiczny, scena teatralna, zacisze wypoczynkowe, ogród doświadczalny, ogród zmysłów lub złudzeń, elementy rekreacyjne, arboretum, urządzenia sportowe) jedynym wskazanym pomysłem było mini arboretum, w którym uczniowie poznawaliby różne gatunki drzew. W ramach wywiadu uzyskano informację, że przedstawiona koncepcja projektowa będzie miała szansę realizacji, ponieważ istnieje możliwość pozyskania funduszy ze środków własnych przy aprobacie Wydziału Edukacji w Olsztynie.

Rozmowa z pracownikiem techniczno-administracyjnym dotyczyła inwestycji w obrębie terenu zieleni podjętych w ciągu ostatnich lat. Ustalono, że został opracowany projekt, którego realizację podzielono na trzy etapy: I - został zakończony, II i III - są częściowo zrealizowane. W ramach zaplanowanych zmian dostosowano boisko do siatkówki plażowej poprzez nawiezienie piasku. Uzyskano tez informację, że w ciągu roku na terenie zieleni przy szkole są prowadzone zabiegi pielęgnacyjne roślin, nawożenie, koszenie, przycinanie, opryski itd.

W celu określenia możliwości zagospodarowania terenu szkolnego poproszono o sugestie nauczycieli różnych przedmiotów, którzy przedstawili swoje pomysły i propozycje.

Na potrzeby realizacji lekcji W-F zasugerowano następujące zmiany:

- lokalizacja boiska do piłki nożnej z dala od okien sali gimnastycznej,

- wysypanie piaskiem dwóch boisk do siatkówki plażowej,

Development of the school area
Materials of International Practical Internet Conference "Challenges of Science" 
- stworzenie ścianki do tenisa ziemnego (squash),

- wykonanie tartanu na bieżni,

- zwiększenie parkingu,

- pokrycie sztuczną murawą boiska do piłki nożnej.

Podczas realizacji lekcji chemii wskazano możliwość wykonywania w terenie badań:

- gleby (np. obecność metali ciężkich, zawartość azotu, fosforu),

- wody (np. odczynu pH, twardości),

- ilości tlenu w powietrzu,

- chlorofilu w liściach roślin,

- odkrywek glebowych.

Do nauki języka polskiego na świeżym powietrzu byłyby przydatne:

- ogród złudzeń (np. do nauki impresjonizmu),

- scena do przedstawień teatralnych.

Na potrzeby katechezy w szkole można byłoby urządzić:

- mini ogród biblijny (także do nauki etyki),

- Świątynię dumania jako miejsce wyciszenia i medytacji.

$\mathrm{Na}$ lekcjach z przysposobienia obronnego w otoczeniu szkoły można zorganizować:

- naukę pierwszej pomocy medycznej,

- zajęcia z terenoznawstwa.

Podczas lekcji historii w otwartej przestrzeni wskazano następujące pomysły:

- inscenizacja kampanii, rewolucji, bitew itp.,

- utrwalanie wiedzy na szkolnym Szlaku Królów Polski.

Nauczanie biologii ułatwiłyby takie rozwiązania:

- arboretum oraz ogród z ziołami i innymi roślinami pożytecznymi dla człowieka,

- tabliczki z opisami ciekawych okazów drzew i krzewów.

Na lekcjach geografii w terenie pomocne w nauce byłyby:

- wyryta sieć rzek Polski, Europy i świata na kamiennych płytach wokół szkoły,

- ścieżka edukacyjna przy szkole z wybranymi nazwami geograficznymi.

Z doświadczeń fizycznych do szczególnie ciekawych propozycji należały:

- kołowrotek napędzany siłą ludzkich mięśni do wytworzenia prądu, którym można uruchomić np. fontannę;

- doświadczenia prezentujące złudzenia optyczne.

Analizy uwarunkowań terenu oraz wyników sondażu i wywiadu były podstawą prac projektowych. W ramach badań sporządzono dwie propozycje zagospodarowania terenu szkolnego jako przestrzeni sensoryczno-edukacyjnej. Opracowanie graficzne obu koncepcji wraz z wizualizacjami zobrazowano na rys. 10-14 (I koncepcja) oraz rys.15-17 (II koncepcja).

Pierwsza $\mathrm{z}$ zaprezentowanych koncepcji nadaje terenowi szkolnemu cechy ogrodu dydaktyczno-doświadczalnego, odpowiadając przewodniej idei prac projektowych, jak urządzenie kreatywnej przestrzeni dla młodzieży (rys. 10). Na projektowanym terenie zaplanowano ,zielone klasy”, czyli miejsca do odbywania różnych zajęć na świeżym powietrzu. Źródłem inspiracji do ich wyposażenia były instalacje w ogrodach doświadczeń istniejących w Polsce. $\mathrm{W}$ jednej $\mathrm{z}$ ogrodowych klas przewidziano prezentację doświadczeń chemicznych, w innej obserwację złudzeń optycznych, $w$ kolejnej naukę $\mathrm{z}$ globusem ogrodowym i wyeksponowaną mapą Unii Europejskiej, która jest również elementem nawiązującym do nazwy szkoły (im. Wspólnej Europy). Z wydzielonych wnętrz mogą korzystać nauczyciele różnych

Development of the school area
Materials of International Practical Internet Conference "Challenges of Science" 


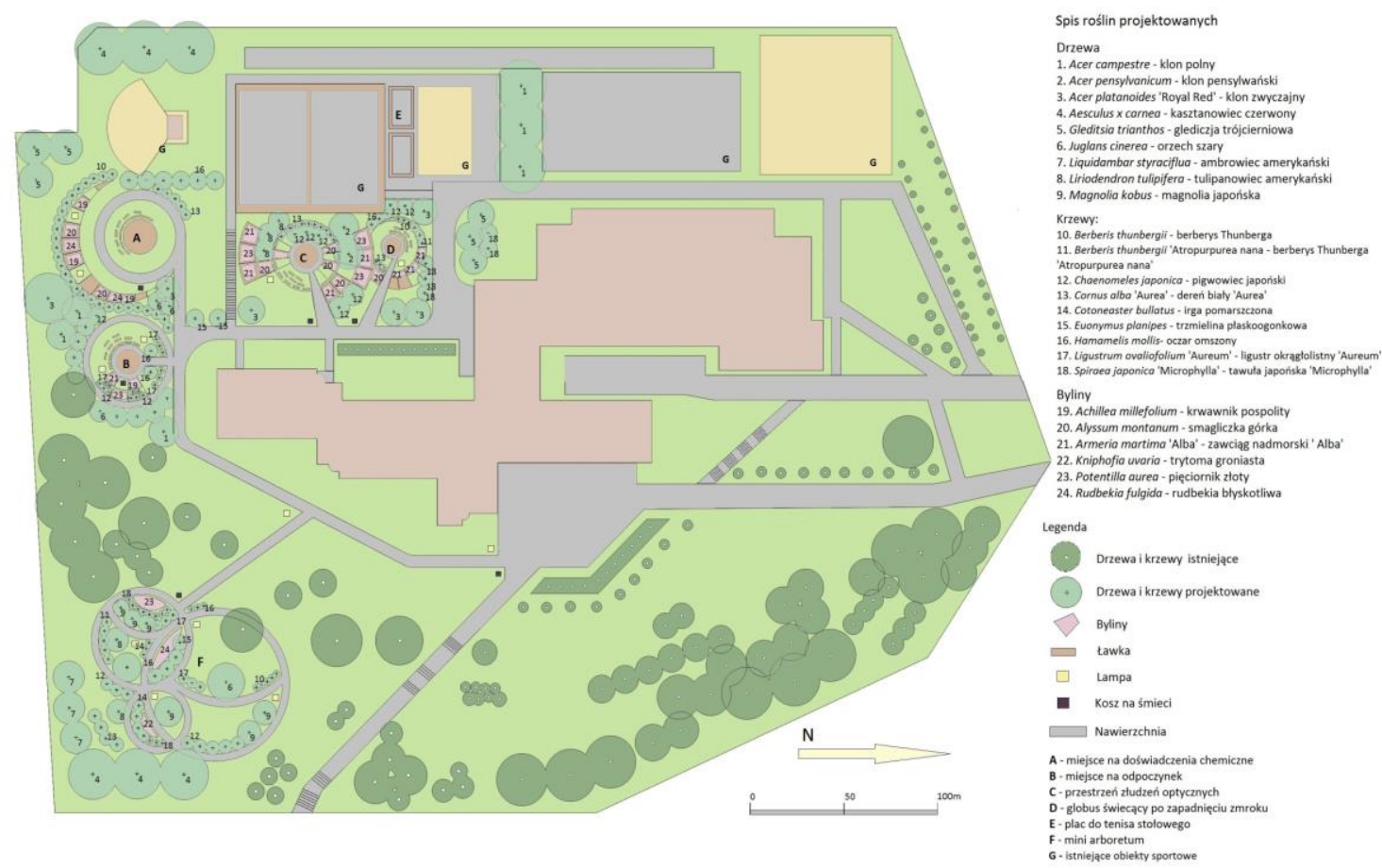

Rys. 10. Przykładowa koncepcja projektowa zagospodarowania terenu przy LO Vw Olsztynie

przedmiotów, wybierając z programu nauczania treści możliwe do realizacji w otoczeniu szkoły. Mini arboretum pogłębi wiedzę botaniczną uczniów oraz umożliwi poznawanie niezbędnych prac pielęgnacyjnych. Zaprojektowano też miejsca do biernego i aktywnego wypoczynku z miejscami do gry $\mathrm{w}$ tenisa stołowego. Wszystkie urządzenia są wtopione $\mathrm{w}$ zieleń komponowaną, która pełni funkcje edukacyjną i estetyczną (rys. 11-14).

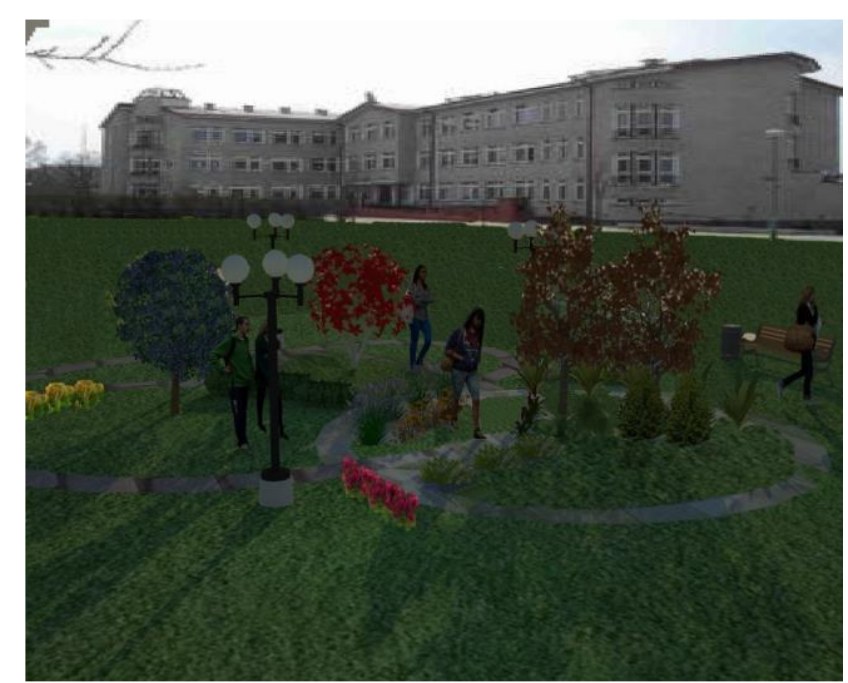

Rys. 11. Mini arboretum przy LO V w Olsztynie

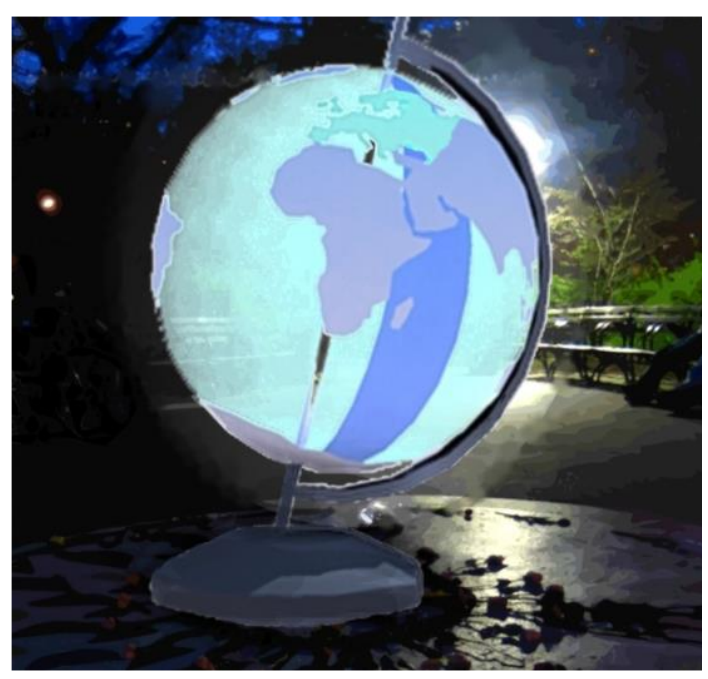

Rys. 12. Podświetlany globus przy LO Vw Olsztynie
Development of the school area
Materials of International Practical Internet Conference

"Challenges of Science" 


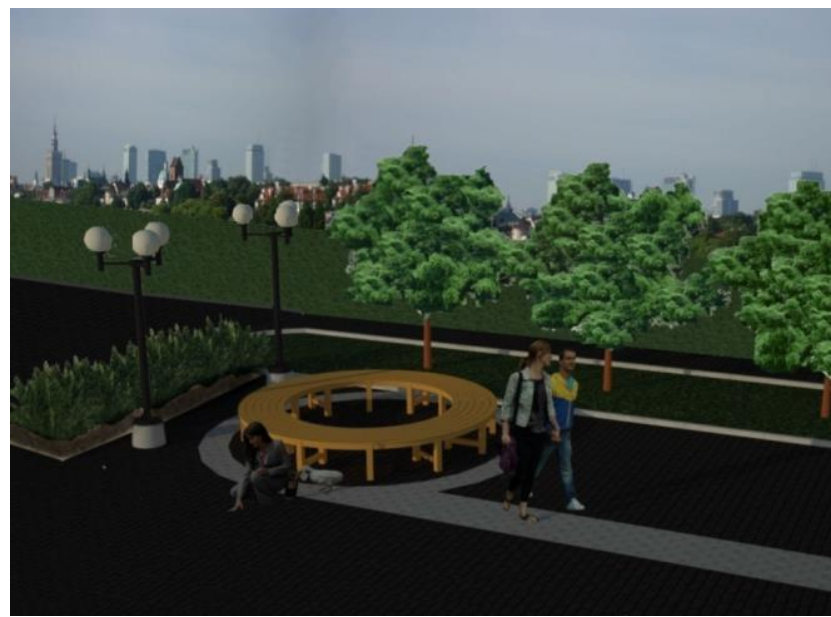

Rys. 13. Miejsce do odpoczynku przy LO Vw Olsztynie

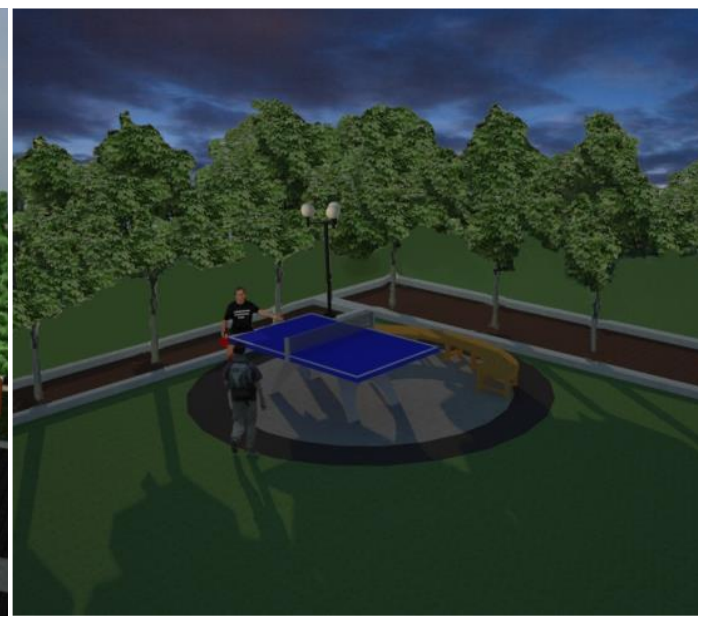

Rys. 14. Plac do tenisa stołowego przy LO Vw Olsztynie

Źródło rys. 10-14: opracowanie graficzne na potrzeby akcji zagospodarowania terenów szkolnych „Ogród z klasq - przestrzeń z wyobraźniq” (opiekun naukowy: dr inż. I. Polucha, grupa projektowa: A. Kotowska, K. Kwiatkowska, M. Łuczak)

Druga koncepcja projektowa, nawiązująca do układu zainspirowanego falą i aktywnością artystyczną młodzieży w ramach street art, w tym graffiti, ma pobudzać kreatywność uczniów (rys. 15). Kompozycja „ogrodu na fali” obejmuje swobodne i płynne linie, tworząc przestrzeń o charakterze naturalistycznym. Taka kompozycja harmonijnie współgra $\mathrm{z}$ istniejącym drzewostanem, bryłą budynku szkoły, a także $\mathrm{z}$ elementami sportowymi występującymi na terenie szkolnym. Ogród przy szkole powinien być przede wszystkim funkcjonalny, dlatego uwagę skupiono głównie na programie użytkowym. Schemat funkcjonalny uwzględnia podział terenu na strefy: reprezentacyjną, dydaktyczno-rekreacyjną, sportową, śniadaniową, artystycznowypoczynkową, gier i parkingową.

Zaprojektowana przestrzeń ma służyć realizacji zajęć dydaktycznych i rozwojowi uczniów, jak również spełniać funkcję miejsca do odpoczynku w czasie przerw. W poszczególnych częściach ogrodu zaproponowano urządzenia pozwalające na rozwój zainteresowań uczniów, a także na prowadzenie zajęć na świeżym powietrzu z różnych przedmiotów. W pobliżu budynku szkolnego wydzielono ,zieloną salę”, nazwaną kręgiem doświadczeń chemicznych i fizycznych (rys. 16). Na placu gier przewidziano stoły do tenisa ziemnego i gry w szachy. Ważnym miejscem spotkań uczniów podczas przerw jest strefa śniadaniowa. Rozwojowi sensorycznemu ma służyć ogród zmysłów ze starannie dobranymi nasadzeniami roślin oddziałujących na zmysły i wabiących owady (tab. 1, rys. 17). Podobną funkcję pełni ścieżka traw, także miejsce do odpoczynku pod dębami z półleżącymi ławkami oraz łąka kwietna. Scena plenerowa z przesuwnymi ławkami pozwoli na rozwój umiejętności aktorskich i muzycznych oraz organizację warsztatów artystycznych. Rolę edukacyjną będzie pełnić droga iluzji, wzdłuż której zaprojektowano elementy tworzące złudzenia optyczne oraz ścianki do artystycznego graffiti. Arboretum tworzyłyby wybrane na całym terenie szkolnym istniejące nasadzenia drzew i krzewów, których rozpoznawanie ułatwią tabliczki z nazwami gatunków roślin oraz opracowana mapa $z$ oznaczonymi okazami i opisem ich cech rozpoznawczych. Do przestrzeni szkolnej warto wprowadzić urządzenia zachęcające do ćwiczeń sportowych osoby, które nie preferują gier zespołowych, jak m.in. trampoliny oraz

Development of the school area
Materials of International Practical Internet Conference

"Challenges of Science" 

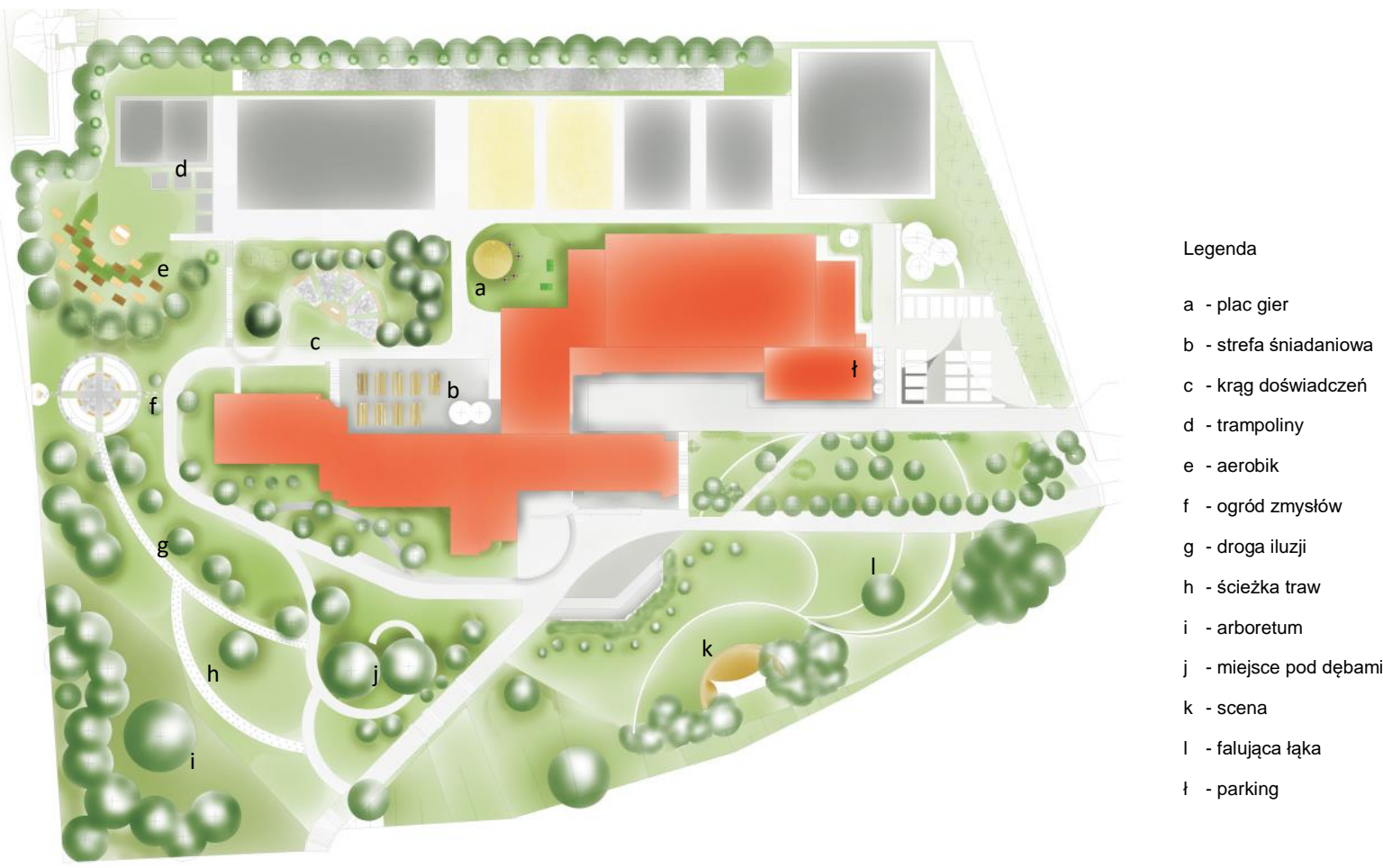

Rys. 15. Propozycja zagospodarowania terenu przy LO Vw Olsztynie

przyrządy do uprawiania aerobiku, ewentualnie siłownia plenerowa. W koncepcji zmieniono układ istniejących boisk sportowych, poprawiając bezpieczeństwo tej strefy. Zaplanowano też dodatkowe miejsca parkingowe.

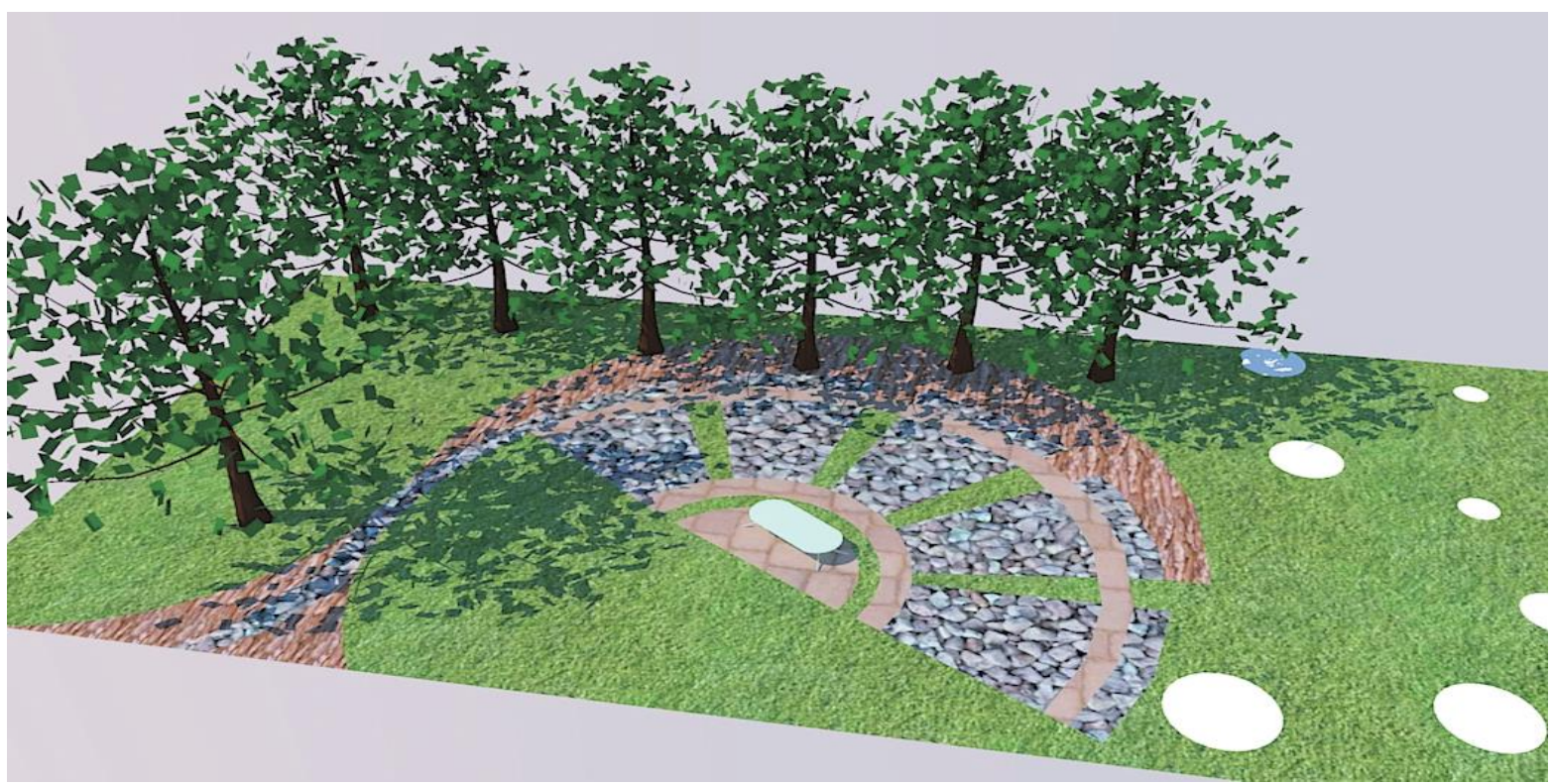

Rys. 16. Widok na krąg doświadczeń na terenie LO Vw Olsztynie

Tabela 1

Development of the school area
Materials of International Practical Internet Conference "Challenges of Science" 
Projektowane gatunki roślin w ogrodzie zmystów przy LO V w Olsztynie

\begin{tabular}{|l|l|}
\hline WZROK & WECH \\
Liatris spicata - liatra kłosowa & Lavendula angustifolia - lawenda wąskolistna \\
Echinacea purpurea - jeżówka purpurowa & Monarda hybrida - pysznogłówka ogrodowa \\
Geranium sp. - bodziszek & Mentha sp. - mięta \\
Astilbe japonica - tawułka japońska & Dianthus sp. - goździk \\
\hline SŁUCH & DOTYK \\
Lunaria annua - miesięcznica roczna & Stachys byzantina - czyściec wełnisty \\
Physalis alkekengi - miechunka rozdęta & Senecio cineraria - starzec srebrzysty \\
Campanula glomerata - dzwonek skupiony & Eryngium sp. - mikołajek \\
Festuca rubra - kostrzewa czerwona & Luzula nivea - kosmatka śnieżna \\
\hline
\end{tabular}

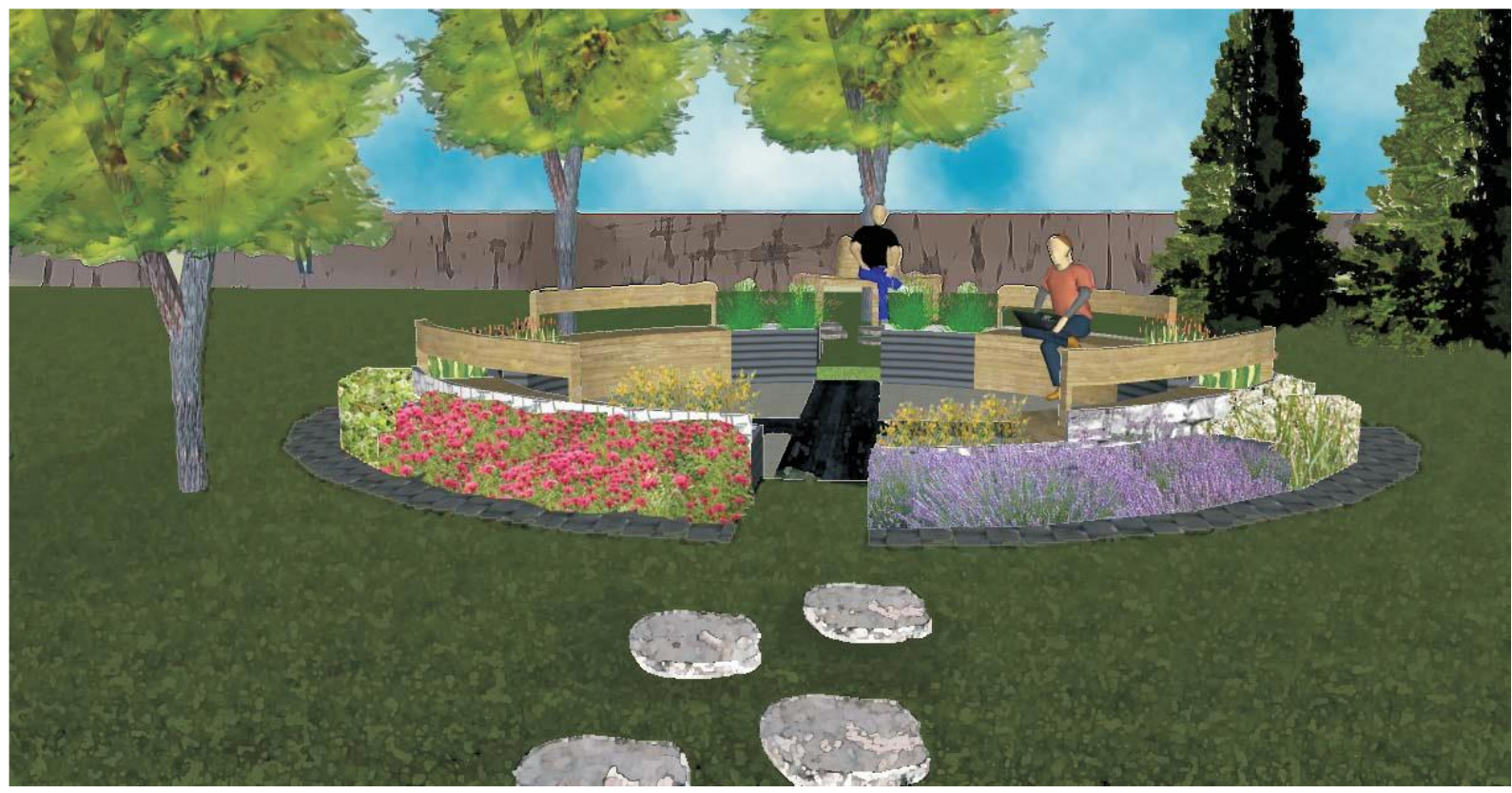

Rys. 17. Widok na ogród zmystów przy LO Vw Olsztynie

Źródło rys. 15-17: opracowanie graficzne na potrzeby akcji zagospodarowania terenów szkolnych „Ogród z klasq - przestrzeń z wyobraźniq” (opiekun naukowy: dr inż. I. Polucha, grupa projektowa: K. Karbowska, J. Kowalewska, Z. Liedtke, A. Kocięcki, A. Łysiak)

\section{Podsumowanie}

Przestrzeń sensoryczno-edukacyjna dostarcza wiele możliwości rozwoju zainteresowań i kreatywności uczniów. Celem kształtowania takiej przestrzeni jest stworzenie inspirującego środowiska do nauki, które będzie poruszać wszystkie zmysły uczniów. Innowacyjnie zagospodarowana przestrzeń $\mathrm{w}$ otoczeniu szkół motywuje nauczycieli do alternatywnego podejścia do nauki, wychodzenia poza sformalizowane ramy kształcenia. Warto konstruować programy nauczania $\mathrm{w}$ taki sposób, żeby doświadczenia $\mathrm{z}$ otoczenia zewnętrznego, były uzupełnieniem standardowych zajęć. Różnorodność doświadczeń edukacyjnych przyczynia się bowiem do kompleksowego rozwoju uczniów, zarówno fizycznego, jak i umysłowego.

Nieocenionym źródłem pomysłów na urządzenie terenów szkolnych ogrodów zmysłów mogą być uczelnie. Wspieranie placówek dydaktycznych w zakresie prac projektowych pozwala

Development of the school area
Materials of International Practical Internet Conference "Challenges of Science" 
zainicjować działania zmierzające do powiązania nauki z praktyką i kształtowania funkcjonalnej i estetycznej przestrzeni poprzez nadanie jej funkcji sensoryczno-edukacyjnej. Propozycje przygotowane $\mathrm{w}$ ramach zajęć projektowych pod nadzorem pracowników szkół wyższych są poprzedzone gruntownymi badaniami, w tym rozpoznaniem terenu, warunków klimatycznych i glebowych, inwentaryzacją zieleni, analizami krajobrazową i przestrzenną, sondażami $\mathrm{z}$ pracownikami placówek edukacyjnych i uczniami.

Przestrzeń przyszkolna może zyskać nowy wymiar, ponieważ inspiracją do tworzenia projektów zagospodarowania terenów przyszkolnych są rozwiązania stosowane w parkach nauki, sportu i kultury, w ogrodach sensorycznych, edukacyjnych, terapeutycznych itp. Warto zwrócić uwagę na tematy zajęć m.in. z zakresu z fizyki, astronomii, optyki, biologii, chemii, geografii, języka polskiego i języków obcych, plastyki czy muzyki itp., które można z powodzeniem rozwijać w przestrzeni ogrodowej. Należy poszukiwać instalacji pozwalających na przeprowadzanie eksperymentów w ogrodzie oraz atrakcyjnych urządzeń i elementów małej architektury o charakterze edukacyjnym. W ramach szeroko pojętych prac projektowych możliwy jest również dobór gatunków roślin o szczególnych walorach wizualnych, zapachowych czy smakowych, dzięki którym przestrzeń przyszkolna zyskuje funkcję sensoryczno-edukacyjną. W przestrzeni przyszkolnej można zastosować proste urządzenia zachęcające do aktywności sportowej i stymulujące rozwój motoryczny, a także służące integracji sensorycznej uczniów.

\section{Bibliografia}

Bernat S. 2008. Inicjatywy publiczno-prywatne w zakresie ksztaltowania krajobrazu dźwiękowego w Polsce. Zarządzanie Krajobrazem Kulturowym. Prace Komisji Krajobrazu Kulturowego nr 10. Komisja Krajobrazu Kulturowego PTG, Sosnowiec, s. 1.

Drozdek E. 2010. Ogród doświadczeń. Zieleń Miejska, Nr 3(6), Marzec 2010, s. 38-39.

Gołąb M. 2007. „Ogród Doświadczeń im. Stanisława Lema w Krakowie”. Foton 96, Wiosna 2007, s. $72-$ 73.

Gruza M. 2009. Bajkowy Ogród Zmystów powstanie na Bielanach. Życie Warszawy.pl http://www.mainegardens.org/discover/image-gallerie (dostęp 20.06.2012).

Latkowska M. J. 2008. Hortiterapia - Rehabilitacja i terapia przez prace $w$ ogrodzie. Zeszyty problemowe Postępy Nauk Rolniczych, str., 229-233.

Ogród doświadczeń w Krakowie. 2007. www.ogroddoswiadczen.pl (dostęp 05.07.2011 r.).

Pawłowska K. 2008. Ogród sensoryczny. Dźwięk w krajobrazie jako przedmiot badań

interdyscyplinarnych. Prace komisji krajobrazu kulturowego. T. XI, Instytut Nauk o Ziemi UMCS,

Komisja Kulturowego PTG, Lublin, s. 143-147.

Piórecki N. 2010. Sensualny ogród uniwersalny. Zieleń Miejska, Nr 4(37), Kwiecień 2010, s. 34-36.

Stownik języka polskiego. 1995. PWN, Warszawa.

Wypychowska D. 2002. Ścieżki przyrodnicze na terenie Parku Narodowego Ujście Warty. Ekoregion Ujście Warty, nr 6.

Development of the school area
Materials of International Practical Internet Conference

"Challenges of Science" 